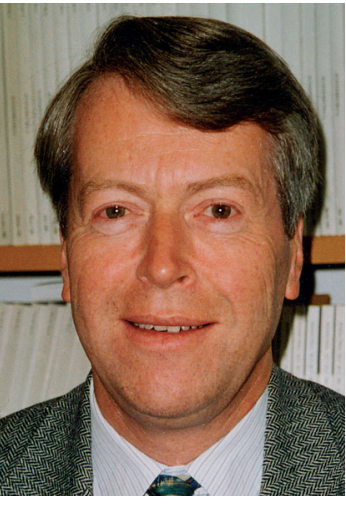

\section{Capital Regulation} AFTER THE CRISIS: BUSINESS AS USUAL?

\author{
Martin HellwiG*
}

\section{Introduction}

In December 2009, the Basel Committee for Banking Supervision has submitted proposals for a reform of the regulation of capital requirements for banks in the wake of the crisis. In its Consultative Document (Basel Committee on Banking Supervision 2009), the Basel Committee observes that banks entered the crisis with too little capital and that the insufficiency of bank capital played an important role in the crisis. To improve matters, it proposes an international harmonization of the definition of capital and the introduction of a leverage ratio, as well as tighter standards for bank liquidity, and various measures to reduce the procyclical effects of capital regulation. The Basel Committee does not, however, present any systematic analysis of why the proposed measures should have the salutary effects that are expected of them.

Nor does the Basel Committee present any systematic analysis of why the existing system of capital regulation has failed so miserably in the crisis. Over the past two decades, this system has been developed and ever more refined with an enormous investment of effort and sophistication. Why then could major banking institutions manage their risks and their equity in a way that materially contributed to the crisis? Why was bank capital so low that, soon, there were doubts about solvency and interbank markets were destroyed by mistrust? What assurance do we have that individual banks or the overall banking system would have fared better if the changes that are now being proposed had already been installed a decade ago? Is it really enough to tighten a screw

* Max Planck Institute for Research on Collective Goods, Bonn. here and put in a new nail there? Or doesn't the entire ship of banking regulation need a thorough overhaul?

The regulatory community seems unwilling to even ask such questions. It adheres to a tradition of discussing the rules of capital regulation among the bureaucratic cognoscenti, in some interaction with the industry, without ever providing any theoretical or empirical analysis of the effects that the measures under consideration are deemed to have - and without heeding outsiders who demand that such analyses should be just as much a precondition for the implementation of new regulatory rules as for the introduction of new pharmaceutical drugs into the market (Hellwig 1996).

\section{Capital regulation and the financial crisis}

It is by now widely recognized that the global financial crisis of 2007-09 was not just a matter of subprime mortgage securitization in the United States having gone astray (Hellwig 2009). Serious though it was, the real estate and mortgage crisis in the United States was no more substantial than, e.g., the Japanese banking crisis of the 1990s that did not take down the global financial system. The real estate and mortgage crisis in the United States ended up taking down the global financial system because the institutions that were involved were more fragile and more interconnected than in previous crises. Moreover, once the crisis broke into the open, in August 2007, the system developed an implosive dynamic of its own, based on the interplay of price decreases in malfunctioning markets, fair value accounting requiring immediate writedowns on the affected assets, an insufficiency of bank capital requiring deleveraging, thus adding to the downward pressure on asset prices. The downward spiral that this interplay generated didn't come to a stop until, in October 2008, the taxpayers of the most important countries were committed to stepping in.

Fragility was due to excessive indebtedness and to excessive maturity transformation. In part, these were due to the development of a shadow banking 
system, institutions outside the domain of banking regulation that financed themselves by issuing shortterm debt in wholesale markets and invested in tradable assets with longer maturities. Thus, conduits and structured-investment vehicles (SIVs) provided banks with a way of investing in asset-backed securities without putting up the equity that would have been required if they had held these investments in their own books. ${ }^{1}$ The guarantees that the sponsoring banks had provided for these vehicles required hardly any equity; nor were these guarantees subjected to large-exposure regulation.

In part, excessive indebtedness and maturity transformation were due to the exploitation of the modelbased approach to capital regulation by banks inside the domain of banking regulation. Many institutions had equity amounting to 1-3 percent of their balance sheets even as they were vaunting themselves as having 10 percent "core capital". The latter quantity, which relates equity to risk-weighted assets, is of course useless if the risk weights have not been chosen appropriately. An example is provided by UBS Investment Bank (UBS 2008), which retained the super-senior tranches of MBS CDOs of their own creation in their own portfolio, avoiding capital charges against the credit risks of these securities through credit default swaps. ${ }^{2}$ The correlation of the counterparty risks of these credit default swaps with the underlying credit risks of the MBS CDOs themselves went unnoticed. ${ }^{3}$

When the crisis broke into the open in August 2007, much of the shadow banking system fell apart. Because rating downgrades induced significant capital losses on assets held by conduits and SIVs, refinancing of these vehicles through the market was no longer forthcoming. In line with the guarantees they had given, the sponsoring banks had to step in. As they did so, they had to take these vehicles into their own books. As a result, they were short of equity; some of them were even insolvent because the vehicles that they had guaranteed had incurred losses that exceeded their own previous equity. For those that were not insolvent, the capital charges against the assets newly taken into their own books created

\footnotetext{
${ }^{1}$ According to Acharya, Schnabl and Suarez (2009), this is the only reason why these investments seemed worthwhile.

2 Thus, in its Annual Report $(2007,87)$, AIG writes that "approximately $\$ 379$ billion ... of the $\$ 527$ billion in notional exposure of AIGFP's super senior credit default swap portfolio as of December 31, 2007 represents derivatives written, for financial institutions, principally in Europe, for the purpose of providing them with reg-
pritions, ulatory capital relief rather than risk mitigation."

3 On the role of such correlations of counterparty risks and underlying risks in derivatives hiding systemic risk, see Hellwig (1995).
}

a need to raise additional capital or to deleverage by selling assets.

A need to raise additional capital or to deleverage by selling assets also arose for institutions that had to take writedowns on asset values in their books and that failed to have "free capital", i.e., capital in excess of regulatory requirements. In the crisis, however, there was only limited scope for raising new capital. Therefore, a lot of deleveraging had to take place. Such deleveraging is unproblematic if it involves a single bank trying to improve the structure of its balance sheet. It is a source of systemic risk, however, if there are many banks trying to improve the structures of their balance sheets by selling assets and reducing their debts. Such simultaneous deleveraging will mainly serve to lower asset prices. The asset price decreases feed back into a need for further writedowns, again cutting into bank equity and creating a need for further deleveraging.

The systemic problem is enhanced by maturity transformation. If economic lifetimes of assets are short, some deleveraging can be engineered, even at the level of the overall system, by not reinvesting when the assets' lifetimes come to an end. If economic lifetimes of assets are long, however, such disinvestment by the overall system is not possible. Houses and long-term mortgages are there and have to be held by someone. Individuals can disinvest by selling them, but the system as a whole cannot do so. ${ }^{4}$ Thus, the various conduits, SIVs and investment banks that held asset-backed securities with medium to longterm maturities and that refinanced themselves by issuing debt of very short maturities contributed to systemic risk not only because they were overindebted but also because their balance sheets contained the seeds of a tremendous deleveraging spiral.

The deleveraging spiral was particularly pronounced because the multipliers for deleveraging were enormous. If equity amounts to 2.5 percent of the balance sheet, one dollar's worth of losses creates a need to sell forty dollars' worth of assets on average in order to bring the capital ratio back into line.

If equity amounts to 2.5 percent of the balance sheet, it also doesn't take long for concerns about solvency to arise. ${ }^{5}$ Such concerns cause frictions for refinanc-

\footnotetext{
${ }^{4}$ For a warning about this, see Blum and Hellwig (1996).

${ }^{5}$ Prior to the crisis, UBS had equity capital equal to CHF 40 billion, with an overall balance sheet of CHF 1,600 billion. Losses on subprime-mortgage backed securities and derivatives amounted to well over CHF 40 billion. If it hadn't been for recapitalization by the government of Singapore and by the Swiss Confederacy, ...
} 
ing, in particular, in the wholesale markets that provided the major source of short-term funding for many institutions. Fears for one's own refinancing prevent institutions from acting as buyers of securities even if prices are deemed to be "too low". Such fears may also create incentives for deleveraging in excess of regulatory requirements, thereby adding to the spiral. From August 2007 until October 2008, there were several episodes where interbank markets broke down and central banks had to step in to replace them. In the end, in the wake of the Lehman insolvency, these markets broke down completely, and the turmoil in the global financial system induced governments to step in and provide wholesale guarantees for financial institutions.

\section{Regulatory capture by sophistication: a brief history of capital regulation}

The focus of banking regulation on bank capital is a recent phenomenon. From the 1930s to the 1970s, banking regulation and supervision focused on market structure, asset allocation rules and interest rates. Between the mid-1970s and the late 1980s, however, these modes of regulation were largely dismantled. They had become dysfunctional because financial innovations, the liberalization of international capital flows, and the revolution in information and communication technologies had intensified competition in financial sectors all over the world.

The Basel Accord of 1988 tried to stop this trend towards deregulation. Under the guise of international harmonization of banking regulation, the Accord stipulated minimum capital requirements for banks. For ordinary credit risks the capital charge amounted to 8 percent of the loan. ${ }^{6}$ Banks were required to have equity capital exceeding the sum of capital charges.

In 1993, the Basel Committee presented a proposal for extending capital regulation to market risks, i.e., the risks from changes in market prices of assets held in the trading books of banks. This proposal, which corresponds roughly to what is now called the "standard approach", was greeted with scorn by the industry. The rigid capital ratios that it stipulated were said to mark a step back from the quality of risk management which sophisticated banking institutions had

64 percent for credit risks in real-estate loans or loans to other banks, 0 percent for loans to sovereign debtors. already achieved through the development of quantitative models with a firm conceptual and empirical foundation. Risk management on the basis of these models was said to be much more precisely attuned to the actual risks that different assets posed for the banks. Following this lobbying, the 1996 Amendment to the Capital Accord to Incorporate Market Risks gave banks the option to determine regulatory capital on the basis of their own risk models rather than the standard approach. "Basel II", the second Basel Accord, which was concluded after long deliberations in the mid-2000's, provides a similar option for credit risks as well as market risks (Basel Committee on Banking Supervision 2004).

The various modifications of "Basel" since the mid1990s have all been designed so improve the risk calibration of capital requirements. The idea was, in principle, that average capital requirements should be unchanged, but regulatory capital should be ever more closely attuned to actual risks in banking. In fact, these modifications have enabled the large, internationally active banking institutions to reduce regulatory capital, more precisely, to use their capital for ever more levered activities. ${ }^{7}$ This development underlies the Basel Committee's finding that, as they went into the crisis, large banks had equity amounting to only 2 percent of their balance sheets (Basel Committee on Banking Supervision 2009, \# 7). The Basel Committee ascribes this finding to various deficiencies of risk models and risk management. It fails to consider the possibility that the very attempt to calibrate regulatory capital towards measured risks might be responsible for the insufficiency of bank equity capital.

The fact that the equity of many banks is much lower than it was before the mid-1990s is not so much due to deficiencies in risk modeling as to the incentives that bank managers have to expand the business of their banks as much as they can get away with. "Economizing on equity", the catch phrase of the industry, is really a euphemism for a strategy that tries to capture the excess returns to equity that are associated with high leverage. If the balance sheet is forty or fifty times equity, even small margins between asset returns and refinancing costs can be turned into substantial returns on equity. In a world of "shareholder value" and "market discipline", in a discourse with analysts, investors and the media that

${ }^{7}$ For an early warning by a regulator that this was to be expected, see the contribution of D. Zuberbühler in Hellwig and Staub (1996, in particular, $768 \mathrm{ff}$.). 
is focused on returns as opposed to risks, bank managers have strong incentives to go after these returns, neglecting the induced risks for creditors, the financial system and last but not least the taxpayer. The deficiencies of risk modeling and risk management that we have seen should at least partly be ascribed to these incentives. Eliminating these deficiencies without addressing the underlying incentives will merely shift the problem elsewhere.

The real problem is one of governance. The Basel process has focused so much on risk calibration that the problem of governance has been neglected. The problem of governance arises because a financial institution's activities can induce substantial risks for the financial system and for the taxpayer. In the absence of regulation, there is no reason why these external effects should be taken into account by bank managers. Regulation and supervision are there to reduce this governance problem. When the model-based approach to capital regulation was introduced, however, the regulatory community was so impressed with the sophistication of recently developed techniques of risk assessment and risk management of banks that they lost sight of the fact that the sophistication of risk modeling does not eliminate the governance problem which results from the discrepancy between the private interests of the bank's managers and the public interest in financial stability. ${ }^{8}$

\section{The illusion of measurability of risks}

The Basel Committee is certainly right in finding that many of the risks that were realized in the crisis had not been properly accounted for in the various risk models that were used to determine regulatory capital under the model-based approach:

- Insufficient account was taken of risks arising from correlations of credit risks in mortgages or mortgage-backed securities and other derivatives. Such correlations arise naturally from a common dependence on underlying factors of macroeconomic significance such as market rates of interest, real-estate prices, or the business cycle. Earlier instances of the problem, which should have served as warnings, occurred in the various

${ }^{8}$ Hellwig and Staub (1996) document a panel discussion held at the time. The governance problem, which was raised in my own contribution, was either overlooked or disregarded by the representatives of the Basel process, the regulatory community as well as the industry. real-estate and banking crises of the late 1980s and early 1990s in the United Kingdom, the Scandinavian countries, Japan, Switzerland and others.

- Insufficient account was taken of risks arising from correlations between counterparty credit risks and underlying risks in derivatives and other hedge contracts. Such correlations arise naturally when the counterparty is concluding many similar contracts at the same time. Earlier instances of the problem, which should have served as warnings, concerned variable-rate mortgages in the 1980s and dollar-denominated loans from international banks to Thai banks and from Thai banks to Thai firms in the mid-1990s. Default rates on the former shot up, e.g., in the United Kingdom, when, in the late 1980s, market rates were very high; default rates on the latter shot up when, following the devaluation of the Baht in 1997, Thai firms, which were doing business in domestic currency, were unable to fulfill their dollar-denominated obligations (see also Hellwig 1995).

- Insufficient account was taken of the possibility that asset prices might tumble because important institutions holding these assets were unsoundly financed and might have to sell. This risk has not recently been observed, but it figured prominently among the reasons why, in 1998, Long Term Capital Management was rescued from immediate insolvency.

The Basel Committee is wrong, however, in looking at these deficiencies as technical flaws that can be corrected by improvements in rules and procedures. These deficiencies should instead be seen as symptoms of more fundamental problems which raise doubts about the model-based approach to capital regulation altogether.

In the first place, the empirical basis for risk modeling is often insufficient. Many of the time series that are being used are very short. Moreover, they tend to exhibit substantial non-stationarities which preclude reliable estimates of the underlying structures. ${ }^{9}$ These problems are particularly serious when it comes to estimating correlations. ${ }^{10}$ For credit risks, there is the added complication that defaults are relatively rare events - unlike changes in asset prices.

${ }^{9}$ I raised these issues in my contribution to Hellwig and Staub (1996). Their relevance in the context of the crisis is documented in UBS's Shareholder Report on UBS's Writedowns (UBS 2008).

${ }^{10}$ For a warning about this prior to the crisis, see Duffie (2007). 
More importantly, many of the risks involved are not exogenously given, but must be seen as endogenous. They depend on the behavior of the parties in question and on the development of the markets in which these parties operate. They change over time, and these changes are hardly observable from the outside. Thus, counterparty credit risks in derivatives and other hedge contracts and the correlations of these counterparty risks with the underlying risks - depend on total exposures of the counterparties from such contracts. These exposures depend on the counterparties' contracts with third parties; if the counterparties are active on both sides of the market, transferring the risks yet to other participants, the exposure also depends on the counterparty credit risks of these further contracts. The notion that these risks are objectively given and can be reliably measured is no more than an illusion. ${ }^{11}$

Some of the endogeneity involves the system as a whole. As I explained in Section 2 above, the downward spiral of the financial system from August 2007 to October 2008 can be understood as a systemic response to a collective deleveraging attempt. Some of the correlations that have been observed arise from the co-dependence of different markets on the factors that drive the overall system. The correlations and non-stationarities that these systemic factors induce are hardly amenable to measurement, let alone reliable measurement.

\section{Conceptual deficits of capital regulation}

In discussions with industry representatives or members of the regulatory community, I am often asked the rhetorical question “Don't you agree that a system of regulation that calibrates capital requirements to risks is better than a system of regulation that fails to do so." The presumptions behind this question have dominated the discourse about capital regulation since the early 1990s. However, as long as the context is not clear, as long as the objectives and the presumed functioning of capital regulation have not been specified, the question is ill-posed. I might as well answer that the Soviet Union's five-year

${ }^{11}$ Interestingly, the Basel Committee's Consultative Document (\# $112 \mathrm{ff}$.) only calls for a consideration of counterparty risks in hedge contracts without explaining how this is to be done. The role of correlations with the underlying, the variable that really matters, is not even discussed. plans under Breshnev were better than those under Stalin, before the computer age. ${ }^{12}$

The regulatory community as well as industry must take the blame for never having specified the objectives and the presumed functioning of capital regulation. Ever since it started, with the deliberations about Basel I, discussion about the development and refinement of capital regulation has suffered from the following deficits:

- The precise objective of the regulation is unclear.

- The dynamics of implementation over time have not been given sufficient attention.

- Systemic concerns have been neglected.

These deficits are one reason why, even if they knew that risk calibration was mainly a tool to reduce capital requirements, the regulatory community has been unable to put up stronger resistance against the industry's claims that capital regulation must be finely attuned to the actual risks that banks are taking. They are also a reason why dysfunctional effects of the regulation have by and large been overlooked.

Objectives: In principle, capital regulation should contribute to maintaining the safety and soundness of banks. How it serves this purpose is usually not explained, at least not beyond the truism that insolvency corresponds to a situation where equity is negative. There seem to be three possibilities:

- Capital serves as a buffer against unexpected losses.

- Capital reduces incentives for incurring risks that might end up burdening creditors or the taxpayer.

- A capital requirement provides the supervisor with room for intervention before the bank becomes insolvent.

In the various documents on banking regulation, all three purposes of capital requirements are named. No account is given, however, of the differences between them, and, in particular, of possible conflicts and trade-offs concerning appropriate standards for determining regulatory capital. Whereas the role of capital as a buffer against losses might call for a cali-

12 The latest example in this discussion is provided by Frenkel and Rudolf (2010), an expertise on behalf of the Bundesverband deutscher Banken, the association of private banks in Germany. The authors acknowledge that the lack of bank equity has played a role in the crisis, but oppose the introduction of a leverage ratio approach without risk calibration on the grounds that (i) such a regulation would induce a credit crunch and (ii) deficits in risk-calibrated capital regulation should be eliminated by improving that regulation rather than introducing a bound on leverage ratios. They do not discuss why capital was as low as it was. Nor do they observe that the credit crunch argument against a leverage ratio would apply just as much to an attempt to raise bank equity by improved capital regulation. 
bration with respect to total risk, the role of capital as an incentive device would call for calibration with respect to incremental risks, and, finally, the role of capital regulation as a basis for intervention prior to insolvency would call for a calibration with respect to the ease with which assets can be disposed of during this intervention. The three modes of calibration differ; the differences have so far not been considered.

Dynamics of Implementation over Time: Prior to the crisis, there was no consideration of the paradox that the buffer function of regulatory capital is limited because this capital is needed to satisfy the regulator. The dynamics of implementation over time had not received much attention. Conceptually, the discussion had hardly moved beyond a two-period model where financing and investment decisions are taken in period one, returns are realized and paid out in period two, and then the world ends. In a two-period world, of course, the buffer function of capital and the effects of capital on incentives for risk taking are easily understood.

If one moves from a two-period model to a real world where financing, investment and payout decisions are taken on an ongoing basis, neither the buffer argument nor the incentive argument can be taken for granted. The incentive argument breaks down because today's anticipation of tomorrow's capital requirements can induce additional risk taking today; the reason is that, if the additional dollar of earnings on today's investment can be reinvested tomorrow with a multiplier of fifty, this multiplier enhances the attraction today of gambles that offer large prizes if they succeed (Blum 1999). The buffer argument breaks down when the interplay of price declines, fair-value accounting and capital regulation forces the bank to deleverage by selling assets; such deleveraging may even endanger long-run solvency because, in malfunctioning markets of the sort that we have seen in the crisis, market prices of assets may well be below discounted present values of returns. $^{13}$

In a world with on-going financing and investment decisions of banks, a key question must be how capital regulation ought to be implemented over time, in particular, how the bank's assets and liabilities should be adjusted over time when unexpected losses have caused equity capital to drop. Schemes for

13 For an assessment of market prices versus discounted present values of returns in the crisis, see International Monetary Fund (2008) dynamic provisioning and de-provisioning that are currently under discussion represent a step in this direction. However, I suspect that current plans involve too many illusions about the scope for attuning such dynamics to macro-developments, measurements of cyclicality and the like.

Neglect of Systemic Concerns: Three aspects merit particular mention. First, in the context of risk calibration of regulatory capital, too little attention is paid to the dependence of counterparty credit risk and of market risks on systemic developments. The various correlations that I have mentioned above provide relevant examples. Second, in the context of implementation dynamics, too little attention is paid to the systemic impact of regulation-induced deleveraging. Forcing Bank A to deleverage when it has experienced losses will harm Bank B if Bank A's asset sales depress the prices of securities held by Bank B. If Bank B in turn is induced to sell assets, the backlash may end up hurting Bank A itself. Contrary to the ideology of capital regulation, such deleveraging can hurt the safety and soundness of the institutions that are forced into it.

Third, the model-based approach to determining capital regulation has increased the susceptibility of financial institutions to systemic developments. Two mechanisms seem particularly important. First, by encouraging banks to engage in derivative transactions as a way of removing risks, if not out of their books, at least out of their models, the model-based approach has contributed to enhancing the interconnectivity of the system. There is thus more room for domino effects than there used to be. The fate of AIG is a case in point. Second, because, under the modelbased approach, capital requirements for market risks tend to be lower than capital requirements for credit risks, this approach has encouraged banks to put as many assets as possible into their trading books rather than their credit books. They were thus more vulnerable to book losses arising from changes in asset prices arising from market malfunctioning and/ or other institutions' deleveraging.

\section{Conclusion}

The preceding analysis shows that it is not enough to tighten a screw here and put in a new nails there. The system of banking regulation as a whole needs a thorough overhaul. Such an overhaul should pursue two major objectives: 
- We should get away from the illusion that regulation should be finely attuned to the risks that banks are taking. The attempt to do so has been a major factor in the decline in the banks' equity relative to the volume of their activities.

- We should aim for substantially higher regulatory capital, well above ten percent and perhaps even closer to the twenty or thirty percent that was common before banks became used to the idea that the taxpayer couldn't afford to let them fail. Such high capital requirements would still be procyclical. However, deleveraging multipliers between 3 and 4 are much to be preferable to deleveraging multipliers of 40 or 50. Moreover, interbank markets would be much less likely to be perturbed by worries about solvency.

At this point, the banking community will object, saying that equity capital is scarce and expensive. However, I have never yet seen an argument as to why the social cost of bank equity should be high. There may be a high private cost, though even that may be questioned. In any case, the 25 percent or so required rate of return on equity that some bank managers claim is the market's benchmark for banks is not an appropriate measure of either private or social costs of bank equity. This benchmark itself is a result of the industry's being undercapitalized; it reflects the risks induced by this undercapitalization. The fact that risks are reduced if the bank has more equity capital is neglected if the benchmark is taken as given. Some of this risk reduction will provide a private benefit to the bank itself, involving better conditions on newly issued dept - and even a lowering of the marginal cost of equity capital itself. ${ }^{14}$ Some of the risk reduction will provide benefits to existing creditors, to the rest of the financial system and to taxpayers. While these benefits may not figure in the bank's own calculations, they ought to be part of any evaluation of the social costs and social benefits of having high and nonmanipulable equity requirements.

\section{References}

Acharya, V., P. Schnabl and G. Suarez (2009), Securitization without Risk Transfer, Stern School of Management, New York University http://pages.stern.nyu.edu/ sternfin/vacharya/public_html/acharya_ schnabl_suarez.pdf.

AIG Annual Report (2007), http://www.ezodproxy.com/AIG/2008/ AR2007/HTML2/aig_ar2007_0087.

Basel Committee on Banking Supervision (2009), "Strengthening the Resilience of the Banking Sector", Consultative Document, Bank for International Settlements, Basel, http://www.bis.org/publ/ bcbs164.pdf?noframes=1.

Basel Committee on Banking Supervision (2004), International Convergence of Capital Measurement and Capital Standards: A Revised Framework, Bank for International Settlements, Basel 2004.

Blum, J. M. (1999), "Do Capital Adequacy Requirements Reduce Risks in Banking?", Journal of Banking and Finance 23, 755-71.

Blum, J. M. and M. Hellwig (1996), "Die makroökonomischen Wirkungen von Eigenkapitalanforderungen für Banken", in D. Duwendag, ed., Finanzmärkte, Finanzinnovationen und Geldpolitik, Schriften des Vereins für Socialpolitik, NF 242, Duncker und Humblot, Berlin, 41-71.

Duffie, D. (2007), Innovations in Credit Risk Transfer: Implications for Financial Stability, Stanford University, Stanford, http://www. stanford.edu/ duffie/BIS.pdf .

Frenkel, M. and M. Rudolf, "Die Auswirkungen einer Leverage Ratio als zusätzliche aufsichtsrechtliche Beschränkung der Geschäftstätigkeit der Banken”, WHU mimeo, Vallendar,(http://www. bankenverband.de/downloads/032010/studie-leverage-ratio-1).

Hellwig, M. (2009), "Systemic Risk in the Financial Sector: An Analysis of the Subprime-Mortgage Financial Crisis", De Economist 157, 129-207.

Hellwig, M. (1996), "Capital Adequacy Rules as Instruments for the Regulation of Banks", Schweizerische Zeitschrift für Volkswirtschaft und Statistik/Swiss Journal of Economics and Statistics 132, 609-12; http://www.sjes.ch/papers/1996-IV-6.pdf.

Hellwig, M. (1995), "Systemic Aspects of Risk Management in Banking and Finance", Schweizerische Zeitschrift für Volkswirtschaft und Statistik/Swiss Journal of Economics and Statistics 131, 723-37; http://www.sjes.ch/papers/1995-IV-9.pdf.

Hellwig, M. and M. Staub (1996), "Capital Requirements for Market Risks Based on Inhouse Models: Aspects of Quality Assessment", Swiss Journal of Economics and Statistics 132, 755-76.

International Monetary Fund (2008), "Containing Systemic Risks and Restoring Financial Soundness", Global Financial Stability Report, http://www.imf.org/External/Pubs/FT/GFSR/2008/01/index.htm.

Miller, M. H. (1995), "Do the M\&M Propositions Apply to Banks?", Journal of Banking and Finance 19, 483-489.

UBS (2008), Shareholder Report on UBS's Writedowns, http://www.ubs.com/1/ShowMedia/investors/shareholderreport?con tentId $=140333 \&$ name $=080418$ ShareholderReport.pdf. 